DOI: https://doi.org/10.36910/6775-2524-0560-2020-41-18

УДК 629.73

Харченко Володимир Петрович, д.тех.наук, професор, проректор з наукової роботи

кафедри аеронавігаційних систем (АНС)

Онищенко Олександр Андрійович, аспірант кафедри аеронавігаційних систем (АНC)

Національний авіаційний університет, м. Київ.

https://orcid.org/0000-0001-7330-9541

\title{
ФАКТОРИ ВПЛИВУ НА ПОЛЬОТИ БЕЗПІЛОТНИХ ЛІТАЛЬНИХ АПАРАТІВ В СТРАТОСФЕРI
}

Харченко В.П., Онищенко О.А.Фактори впливу на польоти безпілотних літальних апаратів в стратосфері. У статтіпроведено аналітичний огляд стратосферних безпілотних літальних апаратів.Встановлено місце стратосферних безпілотних літальних апаратів серед висотних безпілотних апаратів, сформульовано їх основні завдання. Наведено хронологію розвитку, держави і компанії виробники та типові характеристики основних стратосферних безпілотних літальних апаратів. Визначено основні чинники, що впливають на траєкторію польотів стратосферних безпілотних літальних апаратів.

Ключові слова: стратосфера, безпілотні літальні апарати, відхилення, траєкторія польоту, сонячне випромінювання, висотнібезпілотні апарати.

Харченко В.П., Онищенко О.А. Факторы влияния на полеты беспилотных летательных аппаратов в стратосфере. В статье проведен аналитический обзор стратосферных беспилотных летательных аппаратов. Установлено место стратосферных беспилотных летательных аппаратов среди высотных беспилотных аппаратов, сформулированы их основные задачи. Приведены хронология развития, государства и компании производители и типовые характеристики основных стратосферных беспилотных летательных аппаратов. Определены основные факторы, влияющие на траекторию полетов стратосферных беспилотных летательных аппаратов.

Ключевые слова: стратосфера, беспилотные летательные аппараты, отклонения, траектория полета, солнечное излучение, высотные беспилотные аппараты.

Kharchenko V.P., Onishchenko O.A. Factors of influence on flight of unmanned aircraft in the stratosphere. The article provides an analytical review of stratospheric unmanned aerial vehicles. The place of stratospheric unmanned aerial vehicles among high-altitude unmanned aerial vehicles is determined, their main tasks are established. The chronology of development, states and manufacturers and typical characteristics of the main stratospheric unmanned aerial vehicles are given. Features of flights of stratospheric unmanned aerial vehicles are considered.

Key words: stratosphere, unmanned aerial vehicles, deviations, flight trajectory, solar radiation, high-altitude unmanned aerial vehicles.

Постановка проблеми. Найперспективнішою сферою сучасної авіаційної галузі є створення безпілотних літальних апаратів (БПЛА) - високотехнологічних комплексів на основі застосування сучасних інформаційних технологій [1-4]. Останнім часом номенклатура БПЛА була доповненацілою низкою стратосферних БПЛА (це польоти нависотах від 20 км до 30 км) [5-8]. Нагальна потреба у підвищенні ефективності глобального і локального моніторингутериторії визвала появу таких БПЛА [9-12].

Аналіз останніх досліджень і публікацій. Зазначеним питанням присвячено роботи таких вчених як: В. І. Силков, М. М. Митрахович, С. О. Богословець, В. М. Ілюшко, В. П. Харченко, Н. Я. Василин,

Ю. Л. Іванов, А. Л. Рубцов, В. О. Свірко, І. В. Макаров, В. А. Попов,А. Piccard, С. Ryan, С. Peebles, G. Collins, A. Erickson, N. Baldock, M. R. Mokhtarzadeh-Dehghan, L. N. Craig. Але, певні з них ще не повністю досліджені та вивчені, i, в першу чергу, це питання щодо встановлення причин відхилення стратосферних БПЛА від траєкторії.

Метою дослідження є визначення основних чинників, що визивають відхилення БПЛА від траєкторії в стратосфері.

Виклад основного матеріалу дослідження. Аналітичний огляд стратосферних БПЛА. На основі класифікаційної системи EUROUVS [13] стратосферні БПЛА відносяться до висотних безпілотних апаратів: 3 максимальною висотою польоту від 20 км до 30 км; тривалістю польоту 48 годин і більше; радіусом зони польотів від 2000 км і більше.

Стратосферні БПЛА використовують, як у цивільній, так і у військовій сферах. Основними завданнями цих БПЛА в інтересах цивільних організацій $є:$ передавання радіосигналів, і зокрема, 
забезпечення інтернет з'єднання; фотоспостереження; аналіз клімату та радіаційного фону; спостереження в інтересах захисту державного кордону; спостереження в інтересах аграрного сектору тощо. У військовій сфері стратосферні БПЛА (належать до класу III відповідно STANAG 4670 (АТР 3.3.7)) використовують, як ударні бойові комплекси та бомбардувальники.

Для визначення місця стратосферних БПЛА в загальному обсязі БПЛА, що експлуатуються, розглянемо світовий ринок виробництва безпілотних апаратів різних класів. Рентабельність створення цих БПЛА та рівень їх розвитку суттєво залежать від обсягів фінансування науководослідних та дослідно-конструкторських робіт, що проводяться в державних та приватних науководослідних установах. На сучасному етапі рівень фінансування науково-дослідних та дослідноконструкторських робіт по створенню БПЛА складає 28,7 мільярда доларів (за результатами прогнозування з 2014 року по 2023 рік) (рис. 1).Як видно з рисунку 1, що 38 \% усіх витрат припадає на Сполучені штати Америки, а в Азії це27\%. Відповідно розподіл між Західною та Східною Європою складає $18 \%$ та 9\%. Для держав Близького Сходу це - 7\%, а для країн Латинської Америки $1 \%[14]$.

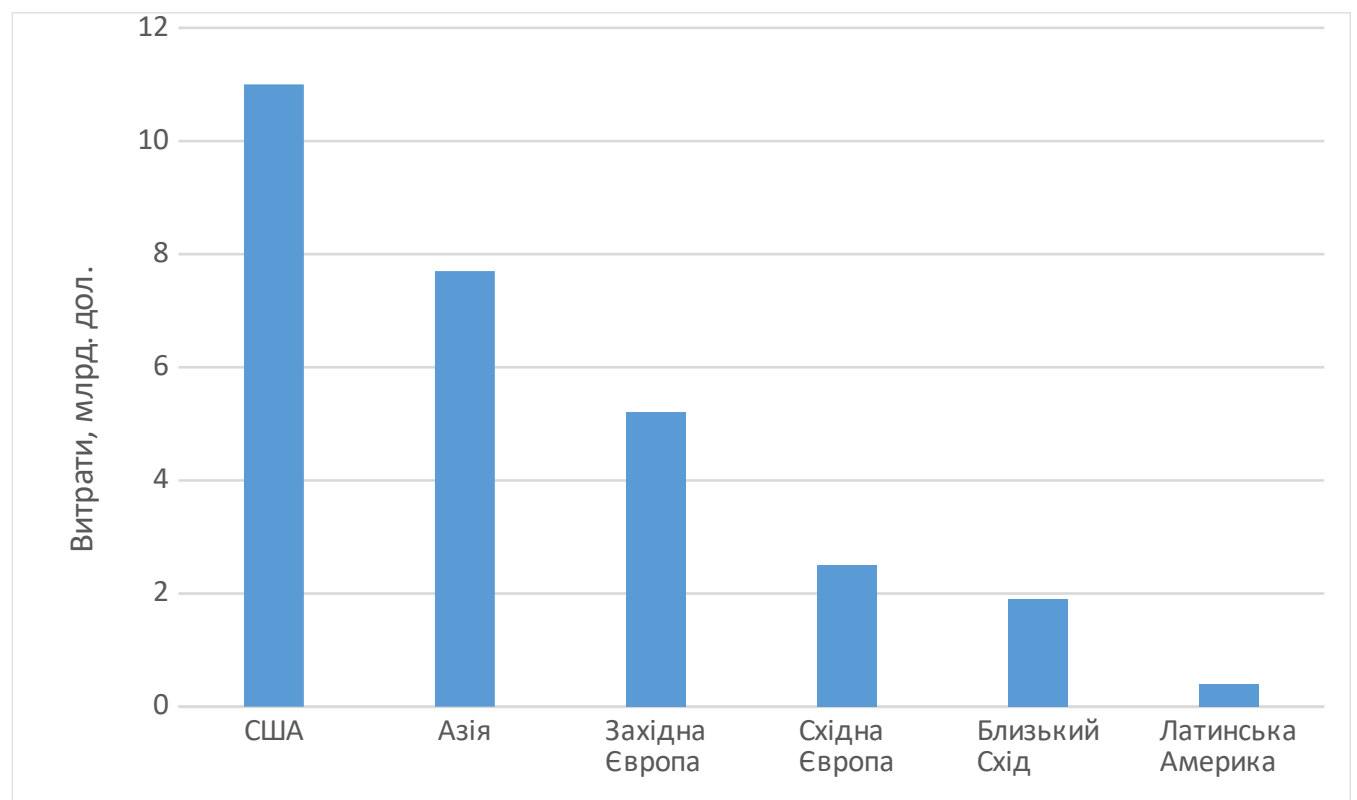

Рис. 1. Результати прогнозування обсягів фінансування створення у світі БПЛА (з 2014 року по 2023 рік) [14]

За результатами прогнозування на 2014-2023 рр. обсяги фінансового забезпечення для створення БПЛА складатиме 35,6 млрд. доларів. На рисунку 2 наведено результати прогнозування обсягів виробництва БПЛА за типами (з 2014 року по 2023 рік).3 рисунку 2 видно, що найбільша частка виробництва (13,7 млрд. дол.)буде виділена для середньовисотних БПЛА великої тривалості польоту класу MALE (Medium Altitude Long Endurance), а найменша частка (1,3 млрд. дол.) - на переносні портативні БПЛА. Створення стратосферних БПЛА обійдеться в 7,3 млрд. дол. На рис. 2 клас UCAV (Unmanned Combat Air Vehicle) - це ударні БПЛА [14]. 


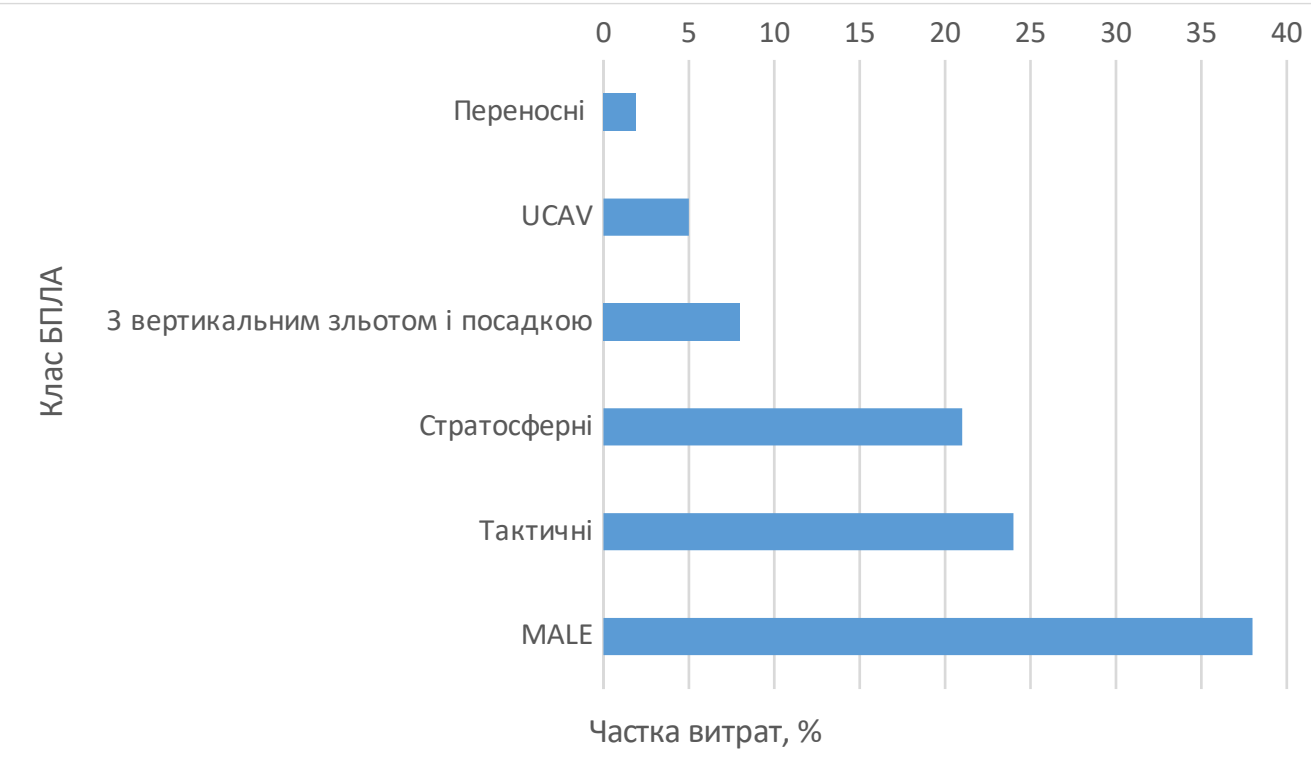

Рис. 2. Результати прогнозування обсягів виробництва

БПЛА закласами (з 2014 року по 2023 рік)[14]

Станом на кінець 2017 року у світі було продано різних класів БПЛА на 7,8 мільярдів доларів (серед них стратосферних БПЛА - на 1,4 мільярди доларів) [15].

В таблиці 1 наведено хронологію розвитку, держави i компанії виробники та типові характеристики основних стратосферних БПЛА [6, 13-19].

Слід відзначити, що важливою перевагою стратосферних БПЛА $\epsilon$ можливість їх використовувати як геостаціонарні супутники, що у поєднанні з сучасними технологіями тривалого знаходження на одному місці забезпечує високу економічну ефективність. Особливо це стосується тих держав де не має альтернативної наземної інфраструктури для стільникового зв'язку (наприклад, у Африці та Індіі). Ці БПЛА мають можливість виконувати спектр завдань притаманних космічним штучним супутникам, наприклад, моніторинг екологічної ситуації, підтримання роботи рятувальних підрозділів, аеро- та теплова зйомка, формування мережі тимчасових комунікаційних і навігаційних систем. На відміну від таких супутників стратосферні БПЛА забезпечують посадку на різного роду поверхні для їх технічного забезпечення і відновлення джерел енергії.

Таблиия 1

Основні стратосферні БПЛА та їх характеристики

\begin{tabular}{|c|c|c|c|c|c|c|}
\hline $\begin{array}{l}\text { Назва } \\
\text { БПЛА }\end{array}$ & $\begin{array}{c}\text { Рік, держава, } \\
\text { фірма } \\
\text { розробник } \\
\end{array}$ & Призначення & $\begin{array}{c}\text { Висота } \\
\text { польоту, } \\
\text { м } \\
\end{array}$ & $\begin{array}{c}\text { Тривалість } \\
\text { польоту, } \\
\text { год. } \\
\end{array}$ & Вага, кг & $\begin{array}{c}\text { Кількість } \\
\text { та тип } \\
\text { двигунів } \\
\end{array}$ \\
\hline $\begin{array}{l}\text { AQM-91A } \\
\text { Compass } \\
\text { Arrow }\end{array}$ & $\begin{array}{l}\text { 1968, США, } \\
\text { Ryan } \\
\text { Aeronautical }\end{array}$ & військове & 24400 & 4,5 & 2381 & 1 ТРДД \\
\hline Орел & $\begin{array}{l}\text { 1986, СРСР, } \\
\text { ОКБ ім. В.М. } \\
\text { Мясіщева }\end{array}$ & військове & 20000 & 34 & 12000 & 2 ПД \\
\hline Condor & $\begin{array}{l}\text { 1988, США, } \\
\text { Boeing }\end{array}$ & цивільне & 20000 & 60 & 9070 & 2 Пд \\
\hline Altus II & $\begin{array}{l}\text { 1997, } \\
\text { CШA,Genera } \\
\text { lAtomics }\end{array}$ & цивільне & 20000 & 24 & 966 & 1 ПД \\
\hline $\begin{array}{l}\text { Pathfunder } \\
\text { Plus }\end{array}$ & $\begin{array}{l}\text { 1998, США, } \\
\text { NASA }\end{array}$ & цивільне & 24445 & 15 & 315 & $\begin{array}{l}\text { сонячні } \\
\text { батареї }\end{array}$ \\
\hline
\end{tabular}


Луц̧ьк, 2020. Випуск № 41

\begin{tabular}{|c|c|c|c|c|c|c|}
\hline Helios & $\begin{array}{l}\text { 1999, США, } \\
\text { NASA }\end{array}$ & цивільне & 29523 & 24 & 929 & $\begin{array}{c}\text { електричн } \\
\text { ий двигун } \\
\text { сонячні } \\
\text { батареї } \\
\end{array}$ \\
\hline Zephyr & $\begin{array}{l}2001, \\
\text { Великобрита } \\
\text { нія, Airbus }\end{array}$ & цивільне & 21000 & 25 діб & 53 & $\begin{array}{l}\text { сонячні } \\
\text { батареї }\end{array}$ \\
\hline $\begin{array}{c}\text { RQ-4 Global } \\
\text { Hawk }\end{array}$ & $\begin{array}{l}\text { 2004, США, } \\
\text { Northrop } \\
\text { Grumman }\end{array}$ & військове & 19812 & 38 & 11612 & 1 ТРДД \\
\hline $\begin{array}{l}\text { ЛА-252 } \\
\text { “Аист" }\end{array}$ & $\begin{array}{l}\text { 2013, РФ, } \\
\text { НВО ім. С.О. } \\
\text { Лавочкіна }\end{array}$ & цивільне & 22000 & 3 місяці & 125 & $\begin{array}{l}\text { сонячні } \\
\text { батареї }\end{array}$ \\
\hline Aquila & $\begin{array}{l}\text { 2016, США, } \\
\text { Facebook }\end{array}$ & цивільне & 27000 & 3 місяці & 399 & $\begin{array}{l}\text { сонячні } \\
\text { батареї }\end{array}$ \\
\hline CH-T4 & $\begin{array}{l}\text { 2017, Китай, } \\
\text { CASC }\end{array}$ & військове & 20000 & 24 & 400 & $\begin{array}{l}\text { сонячні } \\
\text { батареї }\end{array}$ \\
\hline Apus Duo & $\begin{array}{l}\text { 2018, США, } \\
\text { UAVOS }\end{array}$ & цивільне & 20000 & 1 рік & 23 & $\begin{array}{l}\text { сонячні } \\
\text { батареї }\end{array}$ \\
\hline $\begin{array}{l}\text { PHASA- } \\
35\end{array}$ & $\begin{array}{ll}2019, & \\
\text { Великобрита } \\
\text { нія, Вae } \\
\text { Systems }\end{array}$ & цивільне & 21336 & 1 рік & 150 & $\begin{array}{l}\text { сонячні } \\
\text { батареї }\end{array}$ \\
\hline
\end{tabular}

В таблиці 1 введено такі скорочення: ТРДД - турбореактивний двоконтурний двигун;ПД поршневий двигун.

Отже, тривалість польоту сучасних стратосферних БПЛА обмежена в основному запасами палива, тому переклад на енергозабезпечення від сонячних батарей і акумулювання енергії дозволить набагато збільшити час перебування в польоті. В таких БПЛА сонячна енергія в денний час витрачається для здійснення польоту і живлення бортової апаратури, а ії надлишки акумулюються в накопичувачах (електрохімічних акумуляторах, паливних елементах, що здатні до регенерації або суперконденсаторах). Накопичена енергія потім використовуються під час доби, коли енергії Сонця недостатньо для здійснення польоту. Ці БПЛА можуть тривалий час перебувати в польоті, вони надійні, відносно прості в експлуатації, а їх виробництво не вимагає великих фінансових витрат.

Особливості польотів БПЛА в стратосфері. Розглянемо специфіку застосування в стратосфері БПЛА, а саме вплив на БПЛА швидкості вітру, параметрів повітря та сонячного випромінювання.

На рисунку 3 проілюстрована динаміка швидкості вітру в залежності від висоти підйому в стратосфері і вище. 3 рисунку 3 можна бачити, що зміна швидкості струменевих течій відбувається 3 висоти 10 км (максимальне значення - біля $21 \mathrm{~m} / \mathrm{c}$ ) до висот 21-23 км (мінімальне значення - 1-3 м/с), а далі йде практично лінійне зростання швидкості вітру в залежності від висоти підйому. Отже, інтервал висот 21-23 км є найбільш сприятливим для тривалого польоту стратосферних БПЛА [20].

До основних параметрів повітря, що впливають на рух БПЛА в стратосфері відносяться: щільність, температура та в'язкість повітря. Як відомо, зменшення щільності повітря відбувається 3 висотою у відповідності зі змінюванням температури та тиску (щільність повітря пов'язана рівнянням стану газу 3 температурою та тиском повітря). На рисунку 4 показано динаміку змінювання щільності повітря в залежності від висоти польоту[21].

На рисунку 5 проілюстровано динаміку змінювання температури повітря в залежності від висоти підйому в стратосфері і вище. 3 рисунку 5 можна бачити, що при висоті польоту від 20 км до 25 км інтервал температур складає від $-53^{\circ} \mathrm{C}$ до $-51^{\circ} \mathrm{C}$, що може суттєво впливати на працездатність БПЛА. 


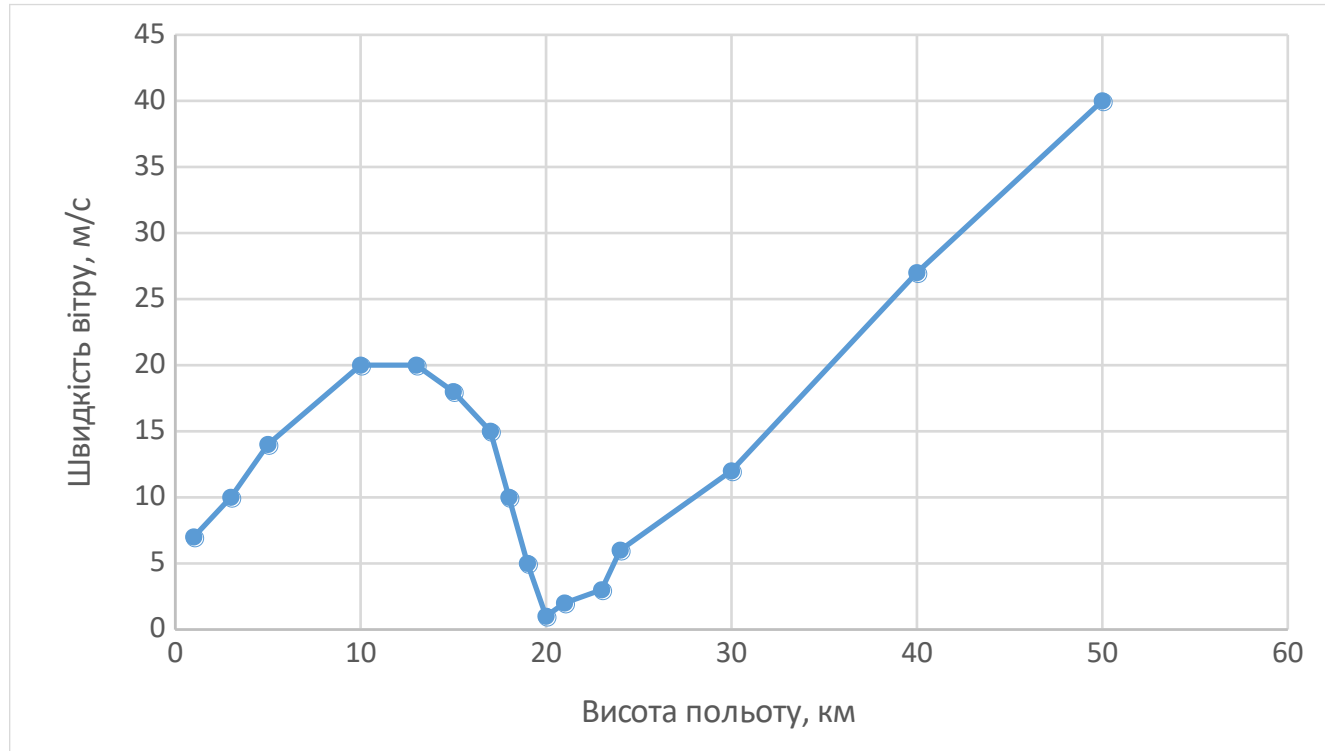

Рис. 3. Динаміка швидкості вітру в залежності від висоти польоту [20]

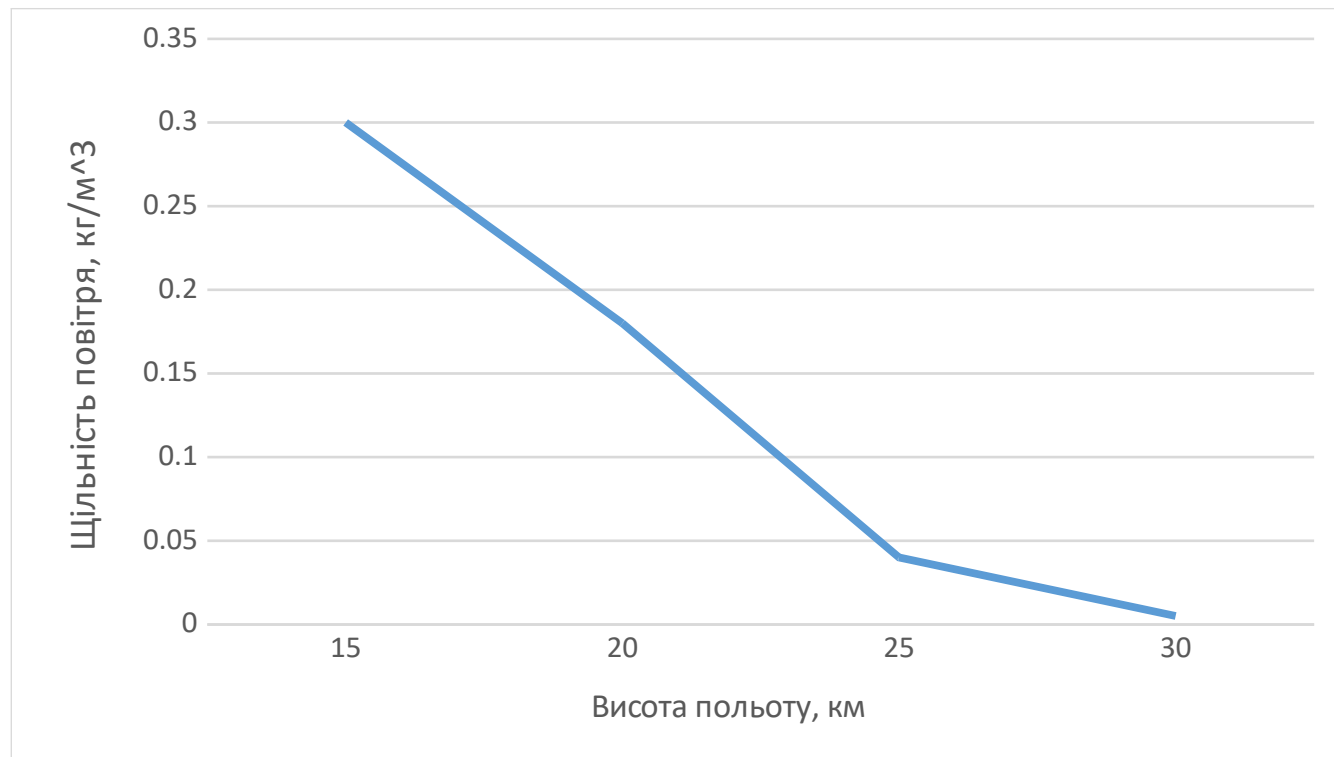

Рис. 4. Динаміка змінювання щільності повітря в залежності від висоти польоту[20]

За умови таких низьких температур може суттєво зменшуватися ємність акумуляторів (і цей фактор треба враховувати). Але вплив від таких температур має і позитивну складову, наприклад, для фотоелектричних перетворювачів їх ефективність зростає (при висоті підйому біля 30 км їх продуктивність збільшується на 10\%).

Ще одним параметром повітря є його в'язкість. Збільшення висоти підйому призводить до змінювання в'язкості повітря (як динамічної, так і кінематичної), це викликає переважання сил в'язкості шарів повітря, що обтікає стратосферний БПЛА, над інерційними силами частинок повітря. Своєрідною мірою між цими силами є число Рейнольдса, яке може характеризувати наступні параметри: прикордонний шар крил БПЛА; точку переходу ламінарного прикордонного в турбулентний шар; точку відривання прикордонного шару; сумарні значення аеродинамічних сил, що вПливають на БПЛА. 


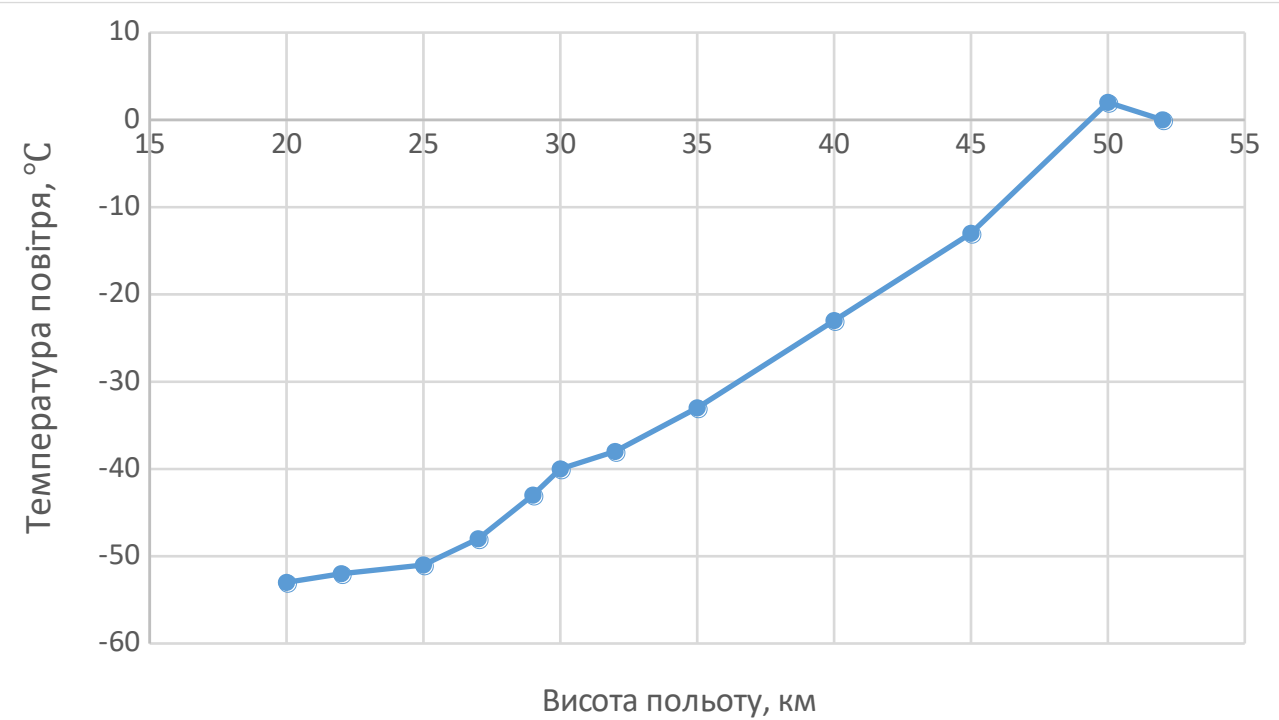

Рис. 5. Динаміка змінювання температури повітря в залежності від висоти польоту [20]

Вплив сонячного випромінювання на БПЛА будемо розглядати як вплив на фотоелектричний перетворювач БПЛА і він залежить від цілої низки чинників, серед яких є:кривизна профілю крил (або крила); орієнтація по земній системі координат; висота підйому (бо істотна частка потужності сонячного випромінювання поглинають атмосферні шари); відстань до Сонця (пов'язано з сезонним положенням Землі до Сонця під час руху у площині екліптики); орієнтація фотоелектричних перетворювачів відносно Сонця (як правило, оптимальним є їх розміщення у горизонтальному i вертикальному оперенні та балках); орієнтація Землі до Сонця залежно від доби та сезонів. Отже, БПЛА споживає різний обсяг сонячного випромінювання (енергії) в різні пори року, часи доби, для різної орієнтації фотоелектричних перетворювачів і географічних координат області, де проходить політ БПЛА. У таблиці 2 наведено середньодобові значення сонячної інсоляції у регіонах Європи (в кВт * год / м^2) в день (нахил на південь, кут нахилу до горизонту 30 градусів)[22].

Таблиия 2

Середньодобові значення сонячної інсоляції у регіонах Європи

(у кВт*г год/м^2) в день (нахил на південь, кут нахилу до горизонту 30 градусів) [22]

\begin{tabular}{|c|c|c|c|c|}
\hline Назва регіону & Весна & Літо & Осінь & 3има \\
\hline $\begin{array}{c}\text { Південна } \\
\text { Європа }\end{array}$ & $4,6-6,3$ & $6,6-7,5$ & $3-5,5$ & $2,6-3,9$ \\
\hline $\begin{array}{c}\text { Північна } \\
\text { Європа }\end{array}$ & $2,6-4,2$ & $4-5$ & $1,2-3,3$ & $0,8-1,5$ \\
\hline $\begin{array}{c}\text { Центральна } \\
\text { Європа }\end{array}$ & $3,6-5,3$ & $5,3-6$ & $2,1-4,4$ & $1,7-3,2$ \\
\hline
\end{tabular}

Висновки та перспективи подальших досліджень. Таким чином, проведено аналіз номенклатури та типових характеристик основних стратосферних БПЛА. Встановлено їх місце серед висотних безпілотних апаратів та визначено основні перспективні завдання для стратосферних БПЛА. Розглянуто специфіку застосування БПЛА в стратосфері та визначено вплив на траєкторію БПЛА швидкості вітру, параметрів повітря та сонячного випромінювання. Подальшим актуальним напрямком досліджень є розроблення підходу до оцінювання відхилення БПЛА від траєкторії в стратосфері з урахуванням їх специфіки застосування.

\section{References}

1. Dolgikh, V.S., Konyshev, D.S., Phil, S.A. (2018). Prospects for the Development of Unmanned Transport Aviation. Open Information and Computer Integrated Technologies, 80, 23-28.

2. Matiichyk, M.P. et al. (2019). Ergodesign of Unmanned Aerial Vehicles: Monograph. Ukrainian Research Institute of Design and Ergonomics. Kyiv: UkrNDIDE, 192 p. 
3. Yefremov, O.V., Korshets, O.A. (2018). Methods of Choosing a Rational Type and Option of Equipment for Unmanned Aerial Vehicles for Combat Missions. Control, Navigation and Communication Systems, 5, 3-7.

4. Zhuravska, I.M., Musiienko, M.P. (2017). Synthesis of Routes of UAVs' Sub-swarms Based on Hopfield Neural Network for Inspection of Territories. Radio electronics. Computer Science. Control, 3, 86-94.

5. Dubinina, M.G, Dubinin, V.V. (2015). Directions of Development of Space and Stratospheric UAVs. Analysis and Modelling of Economic and Social Processes: Mathematics, Computer, Education, 22, 3, 184-191.

6. DARPA. URL: http://www.darpa.mil/NewsEvents/Releases/2014/07/15.aspx (retrieved: 07.10.2020).

7. Brusov, V.S., Piyavsky, S.A. (2016), Multicriteria Analysis of Concepts of High-Altitude Unmanned Aerial Vehicles. Izvestiya VUZov. Russian Aeronautics. No. 4. Pp. 9-12.

8. Popov, V.A. (2020). US Unmanned Combat Aerial Vehicle. URL: http://bp-la.ru/udarnye-bla-ssha/ (retrieved: 06.10.2020).

9. Demchyshyn, M.G. et al. (2018). Use of UAVs in the Environmental Monitoring System: Collective Monograph on the Materials of the XVII International Research and Training Conference; Ed. by: S.O. Dovhyi; Scientific Center for Aerospace Research of the Earth of the Institute of Geological Sciences. Yuston, Kyiv, 85-86.

10. Makarov, I.V. (2020). Application of Satellite Navigation Systems in the Control System of an Unmanned Aerial Vehicle for Remote Ground Sensing Tasks. URL: http://uav-siberia.com/news/primenenie-sputnikovykhnavigatsionnykh-sistem-vsisteme-upravleniya-bespilotnogo-letatelnogo-appara/ (retrieved: 06.10.2020).

11. Romanchenko, I.S. et al. (2016). Models of Application of Information and Telecommunication Technologies on the Basis of Unmanned Aerial Vehicles in Emergencies: Monograph / Ed. by: I.S. Romanchenko, O.I. Lysenko, S.M. Chumachenko; National Aviation University, NAU, Kyiv, 332 p.

12. Makarov, I.V., Kokorin, V.I. (2020). Unmanned Aerial Vehicle Control System for Remote Ground Sounding. URL: http://uavsiberia.com/news/kompleks-upravleniya-bespilotnymi-letatelnymi-apparatamidlya-distantsionnogozondirovaniya-zemli/ (retrieved: 06.10.2020).

13. Blyenburgh van Peter. (2020). Unmanned Aircraft Systems. The Current Situation. URL: https://www.easa.europa.eu/sites/default/files/dfu/ws_prod-g-doc-Events-2008-February-1-Overview-of-the-UAVIndustry-(UVS).pdf (Last accessed: 17.03.2020).

14. Preobrazhensky, N.P. (2020). World UAV Market. URL: https://topwar.ru/38994-mirovoy-rynokbespilotnikov.html (retrieved: 06.10.2020).

15. The Drone Market in Russia and in the World, 2017 (Unmanned Aerial Vehicles, UAVs). (2017). URL: http://json.tv/ict_telecom_analytics_view/rynok-dronov-v-rossii-i-v-mire-2017-gbespilotnye-letatelnye-apparaty-bla-bpla20180427124557 (retrieved: 17.03.2020).

16. Aerovironment's Global Observer: Flying High, Again. (2020). URL: http://www.defenseindustrydaily.com/aerovironmentsglobal-observer-flying-high-again-03902/\#Contracts\&KeyEvents (retrieved: 17.03.2020).

17. Airforce Technology. (2020). URL : https://www.airforce-technology.com (retrieved: 17.03.2020).

18. X-37 Demonstrator to Test Future Launch Technologies in Orbit and Reentry Environments (2020). URL: http://www.nasa.gov/centers/marshall/news/background/facts/x37facts2.html (retrieved: 17.03.2020).

19. Military Factory. (2020). URL: https://www.militaryfactory.com (retrieved: 17.03.2020).

20. Земной климат. (2020). URL: https://zemnoyklimat.ru/page/polety-v-stratosfere/next/10 (retrieved: 06.10.2020).

21. GOST 4401-81. Standard Atmosphere. Parameters. (1984). Introduced 1982-01-07. IPQ. Moscow: Standards Publishing House, $1984.126 \mathrm{p}$.

22. Solar Insolation Data for Ukrainian Cities. (2020). URL: https://solar-tech.com.ua/fannye-solnechnoi-insolyacii-dlyagorodov-ukrainy-2013-06-09.html (retrieved: 06.10.2020). 